\title{
High Intra-Abdominal Pressure Secondary to Obesity as a Determining Factor for Ventriculoperitoneal Shunt Malfunction
}

\section{Aumento da pressão intra-abdominal secundário a obesidade como fator determinante do mau funcionamento de derivação ventrículo-peritoneal}

\author{
Barbara Albuquerque Morais ${ }^{1}$ Vitor Nagai Yamaki ${ }^{1}$ Daniel Dante Cardeal ${ }^{1}$ \\ Fernanda Goncalves Andrade ${ }^{1}$ Wellingson Silva Paiva ${ }^{1}$ Hamilton Matushita ${ }^{1}$ Manoel Jacobsen Teixeira ${ }^{1}$ \\ 1 Department of Neurosurgery, Faculdade de Medicina, Universidade \\ de São Paulo, São Paulo, SP, Brazil \\ Address for correspondence Barbara Albuquerque Morais, \\ Universidade de São Paulo Faculdade de Medicina, Hospital das \\ Clínicas, São Paulo, SP, Brazil (e-mail: babyamorais@gmail.com). \\ Arq Bras Neurocir 2018;37:50-53.
}

\begin{abstract}
The ventriculoperitoneal shunt (VPS) is an established treatment for hydrocephalus. The functioning of the system requires a pressure difference between the cranial and abdominal cavities. The VPS can be particularly problematic in patients with increased intra-abdominal pressure (IAP). We report the case of a 16-year-old girl with VPS since she was 2 months old due to hydrocephalus secondary to myelomeningocele. The patient had been asymptomatic ever since, but she sought the emergency service with intermittent headache and vomiting. A non-enhanced brain tomography, a shunt trajectory X-ray and an abdominal ultrasound revealed no cause of system malfunction. In view of the persistent clinical picture, a revision of the shunt was performed, which revealed adequate intraoperative functioning. She returned with the same symptoms two weeks after surgery. The patient was obese (body mass index [BMI]: 48). We hypothesized intermittent valve malfunction due to increased intra-abdominal pressure. She underwent a ventriculoatrial shunt, without intercurrences. In the postoperative period, the patient presented transient tachycardia and was asymptomatic at the 6-month follow-up. Obesity should be considered an important variable for the

Keywords

- obesity

- ventriculoperitoneal shunt malfunction

- hydrocephalus

- intra-abdominal pressure inadequate functioning of the VPS due to increased IAP and catheter dystocia to the extraperitoneal cavity. Studies have already correlated the IAP with the BMI, which reaches between $8 \mathrm{~mm} \mathrm{Hg}$ and $12 \mathrm{~mm} \mathrm{Hg}$ in obese individuals. Therefore, the BMI can be considered during the selection of valve pressure in systems with non-adjustable valves to prevent insufficient drainage. The recognition of obesity as a cause of VPS malfunction is fundamental to avoid unnecessary surgeries and intermittent malfunction of the system.
\end{abstract}

received

October 16, 2017

accepted

December 4, 2017

published online

March 16, 2018
DOI https://doi.org/

10.1055/s-0038-1623516. ISSN 0103-5355.
Copyright $\odot 2018$ by Thieme Revinter

Publicações Ltda, Rio de Janeiro, Brazil
License terms

(c) $(1) \$$ 


\section{Resumo}

$$
\begin{aligned}
& \text { Palavras-chave } \\
& \text { - obesidade } \\
& \text { - derivação } \\
& \text { ventrículo- } \\
& \text { peritoneal } \\
& \text { - hidrocefalia } \\
& \text { - pressão intra- } \\
& \text { abdominal }
\end{aligned}
$$

A derivação ventriculoperitoneal (DVP) é um tratamento estabelecido para a hidrocefalia; contudo, algumas variáveis podem influenciar na eficácia desta modalidade. $\mathrm{O}$ funcionamento do sistema requer uma diferença de pressão entre as cavidades craniana e abdominal. A DVP pode ser particularmente problemática em pacientes com aumento da pressão intra-abdominal (PIA). Neste artigo, relatamos o caso de uma paciente do sexo feminino, de 16 anos, portadora de DVP desde os 2 meses de idade por hidrocefalia secundária a mielomeningocele. Desde então assintomática, procurou o pronto-socorro com queixa de cefaleia e vômitos intermitentes. Uma tomografia de crânio sem contraste, um raio $\mathrm{X}(\mathrm{RX})$ do trajeto do cateter distal, e uma ultrassonografia (USG) abdominal não evidenciaram a causa do mau funcionamento do sistema. Diante do quadro persistente, realizou-se uma revisão da derivação, que mostrou funcionamento adequado no período intraoperatório. A paciente retornou com os mesmos sintomas duas semanas após a cirurgia. A paciente era obesa (índice de massa corporal [IMC]: 48). Aventou-se possível funcionamento intermitente da válvula pelo aumento da PIA. A paciente foi submetida a uma derivação ventrículo-atrial, que foi realizada sem intercorrências. No pós-operatório, ela apresentou quadro transitório de taquicardia, e não apresentou sintomas no acompanhamento feito depois de 6 meses. A obesidade deve ser considerada uma variável importante para o funcionamento inadequado da DVP, pelo aumento da PIA e pela associação com distocia do cateter para a cavidade extraperitoneal. Estudos já correlacionaram a PIA com o IMC, que pode atingir entre $8 \mathrm{~mm} \mathrm{Hg}$ e $12 \mathrm{~mm} \mathrm{Hg}$ em obesos. Logo, o IMC pode ser considerado na seleção da pressão da válvula em sistemas com válvulas não ajustáveis, para prevenir a drenagem insuficiente. O reconhecimento da obesidade de risco para o mau funcionamento da DVP é fundamental para evitar cirurgias desnecessárias e o mau funcionamento intermitente do sistema.

\section{Introduction}

Hydrocephalus is a neurosurgical entity commonly encountered among the pediatric and adult populations. The ventriculoperitoneal shunt (VPS) is considered the standard treatment for several types of hydrocephali. However, these devices have high rates of complications and failures that require reoperation. Researches have shown that between $30 \%$ and $50 \%$ of VPSs will present some kind of malfunction in the first 12 months. ${ }^{1,2}$ In addition, $41 \%$ of shunt procedures are related to system malfunction, while $7 \%$ are due to infectious complications. ${ }^{1}$

Cerebrospinal fluid (CSF) drainage through VPS is dependent on a differential pressure between the ventricles and the peritoneal cavity. In most cases, fluctuations in the intraabdominal pressure (IAP) will not be of clinical significance. Occasionally, severe constipation, significant ascites and pregnancy may increase the IAP enough to induce high intracranial pressure in shunt-dependent patients.

Recent studies ${ }^{3-5}$ have shown obesity as a possible variable associated to shunt malfunction. The associated mechanisms are increased IAP, catheter dystocia to the extraperitoneal space, and also as an independent factor that alters the CSF physiology. Since obesity is an endemic disease of the 21st century, its role in peritoneal shunt functionality needs to be addressed by more studies. We report the case of a peritoneal shunt that malfunctioned but did not show any evidence of malfunction in the revisions, except for the patient's morbid obesity.

\section{Case Report}

A 16-year-old girl was admitted to the emergency room with moderate to severe headache, nausea and vomiting. She was morbidly obese (body mass index [BMI]: 48), had a history of hydrocephalus secondary to myelomeningocele, and underwent a ventriculoperitoneal shunt surgery when she was 2 months old. When she was 3 months old, she was treated for ventriculitis with external ventricular drainage and antibiotics, followed by a new VPS. The patient had been asymptomatic since then.

Upon admission, a computed tomography (CT) scan showed a mild ventricular dilatation (-Fig. 1) compared with her previous exam. The shunt trajectory image (-Fig. 2) and abdominal ultrasound ruled out any mechanical malfunctions in the system. She was treated conservatively with symptomatic. After this episode, she presented four additional events, but a CT scan did not show any increase in the size of the ventricle. In view of the persistent symptoms, she underwent a shunt revision. The intraoperative finding was a proper distal CSF drainage after the catheter was removed 


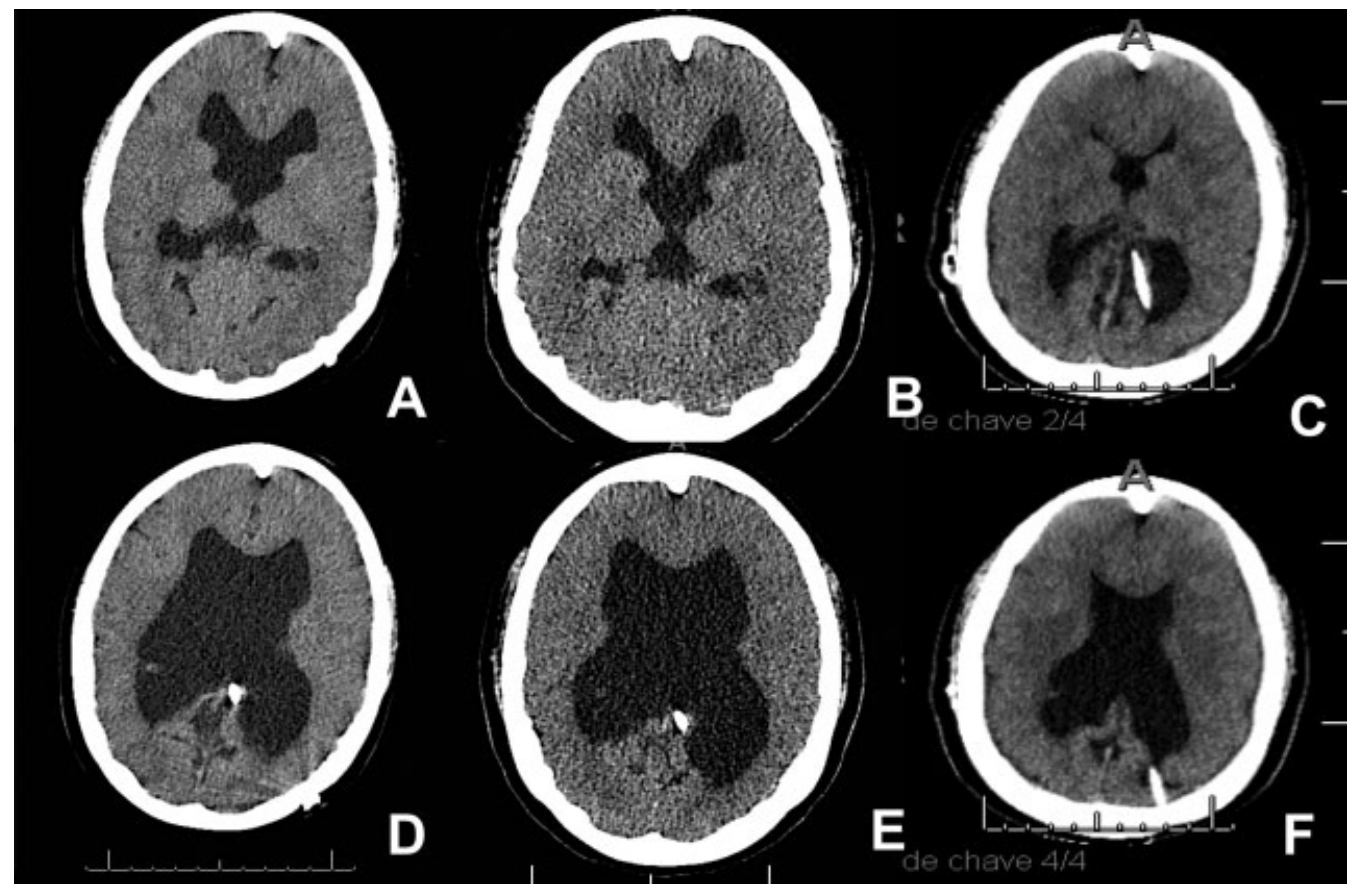

Fig. 1 Axial images of computed tomography (CT) scans of the head. (A, D) pre-operative axial image showing hydrocephalus and the parietal ventricular catheter; (B, E) post-ventriculoperitoneal shunt revision axial images; (C, F) post-ventriculoatrial shunt axial images.

from the abdominal cavity. Intra-abdominal adhesions were not identified. Two weeks after surgery, she returned with the same preoperative symptoms. A complete work-up once more ruled out system malfunction (-Fig. 1). After discarding other possibilities that could be causing the system to malfunction, the patient's morbid obesity was considered, and we performed a ventriculoatrial shunt surgery (-Fig. 3 ). During the postoperative period, she presented only with transient tachycardia. The patient was asymptomatic at the 6-month outpatient follow-up.

\section{Discussion}

Childhood obesity is a serious medical condition that affects children and adolescents; it represents one of the most serious public health challenges of the 21 st century. ${ }^{4,6}$ Thus, a better understanding of the influence of obesity in the functioning of ventriculoperitoneal shunts, CSF physiology and intracranial pressure is mandatory.

Under normal conditions, the IAP is atmospheric $(0 \mathrm{~mm} \mathrm{Hg})$ or slightly subatmospheric. After measuring the IAP with a transurethral catheter in 84 morbidly obese patients, Sugerman et al found that an increase in the sagittal abdominal diameter was associated with a significant increase in the IAP, positively correlating the BMI with the IAP. ${ }^{6}$ In another study, the researchers found that for each $1 \mathrm{~kg} / \mathrm{mm}^{2}$ increase in the normal BMI, there was a $0.07 \mathrm{~mm} \mathrm{Hg}$ increase in the opening pressure in the abdominal pressure. ${ }^{7}$ Therefore, it is estimated that obese patients may have an IAP between $8 \mathrm{~mm} \mathrm{Hg}$ and $12 \mathrm{~mm} \mathrm{Hg}$.

Sahuquillo et $\mathrm{al}^{3}$ published a series of sixty patients who underwent ventriculoperitoneal shunt surgery with an intraoperative measurement of the IAP by an intraperitoneal catheter. The values were correlated to the patient's BMI. In

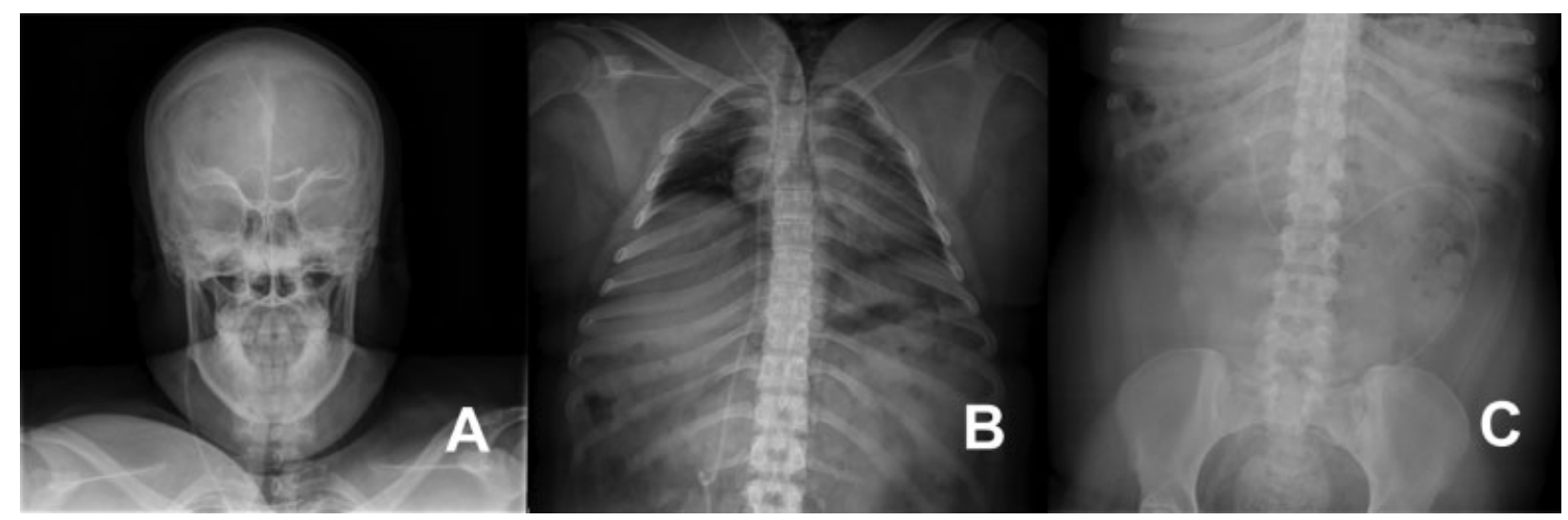

Fig. 2 Head (A), thorax (B) and abdomen (C) radiographs ruled out any mechanical malfunctions of the shunt system. 


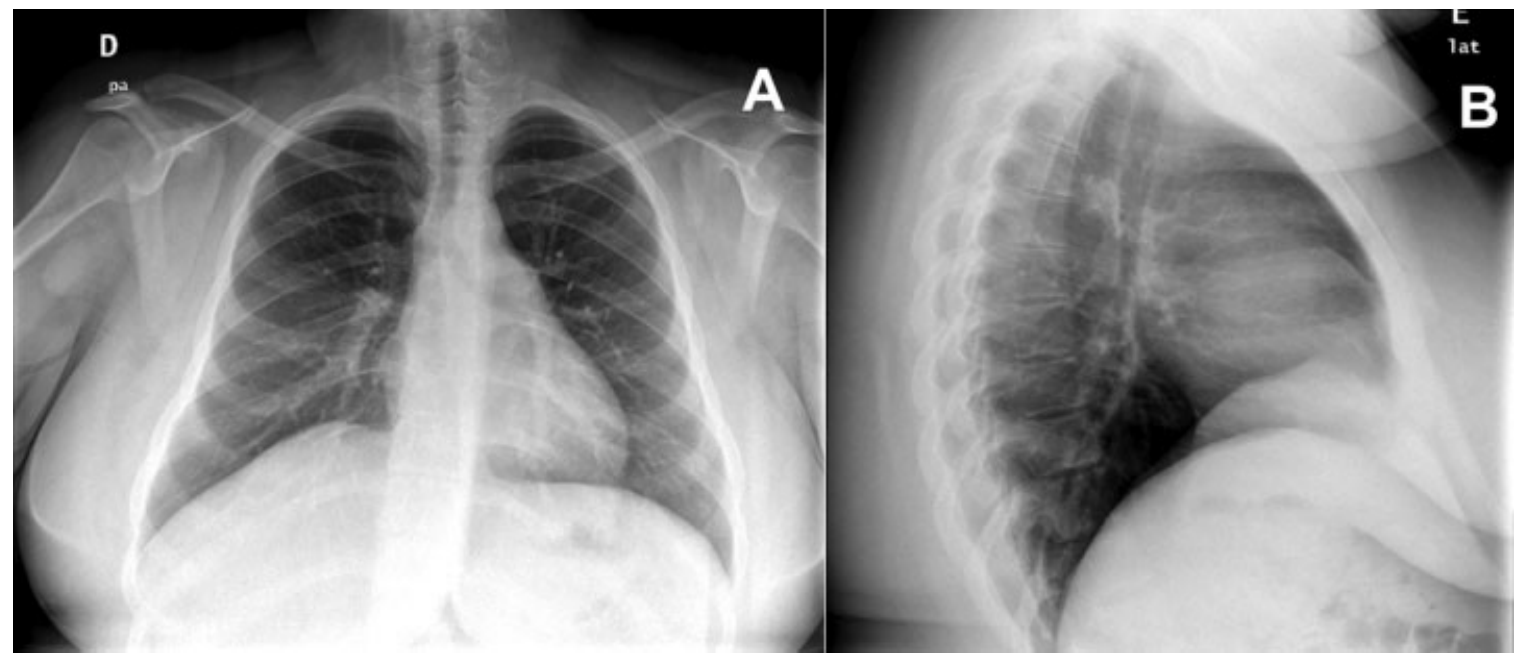

Fig. 3 Anteroposterior (A) and lateral (B) radiographs showing catheter position at the right atrium.

their sample, $30 \%$ of the patients had normal weight, $35 \%$ were moderately overweight, and 35\% were obese. They showed that increases in the BMI positively correlate with increasing IAP values. This is especially relevant for the treatment of normal-pressure hydrocephalus, because a small increase in IAP may impair shunt functioning. Therefore, the researchers suggest that, in obese patients, the neurosurgeons should take the IAP into account when selecting the most adequate differential pressure valve to be implanted, and in which distal cavity to place the distal catheter to avoid shunt underdrainage induced by a high IAP. ${ }^{3}$ In the present case report, we performed a ventriculoatrial shunt, which showed a good outcome during the follow-up.

Previous studies have already associated obesity with shunt malfunction, but, in these cases, the malfunctions were due to catheter migration and dystocia to the extra peritoneal cavity. $5,8,9$

New knowledge supports the association of overweightness not only with increased IAP, but also with high intracranial pressure (ICP). A recent study evaluated 62 subjects who underwent laparoscopic procedures to evaluate the relationship between a high ICP and obesity by measurements of the optic nerve sheet diameter (ONSD) with ocular ultrasonography. ${ }^{4}$ There was a significant difference between obese and non-obese patients, with baseline ONSDs above the cut-off value for increased ICP, indicating chronic increases in ICP. ${ }^{4}$

\section{Conclusion}

Several differentials should be considered regarding the malfunction of a VPS. Obesity should not be neglected when determining the cavity in which to place the distal catheter to avoid unnecessary surgery and intermittent malfunction of the system.

Conflicts of Interest

The authors have no conflicts of interest to declare.
Funding

The authors received no funding to perform the research.

\section{Ethics Statement}

We confirm that this study is original, has never been published, and it is not under consideration by any other journal. This research is in compliance with the ethical standards of our institution, and informed consent was obtained from every participant included in the study.

\section{References}

1 Stone JJ, Walker CT, Jacobson M, Phillips V, Silberstein HJ. Revision rate of pediatric ventriculoperitoneal shunts after 15 years. J Neurosurg Pediatr 2013;11(01):15-19

2 Bergsneider M, Egnor MR, Johnston M, et al. What we don't (but should) know about hydrocephalus. J Neurosurg 2006;104 (3, Suppl)157-159

3 Sahuquillo J, Arikan F, Poca MA, Noguer M, Martinez-Ricarte F. Intra-abdominal pressure: the neglected variable in selecting the ventriculoperitoneal shunt for treating hydrocephalus. Neurosurgery 2008;62(01):143-149, discussion 149-150

4 Dip F, Nguyen D, Sasson M, Lo Menzo E, Szomstein S, Rosenthal R. The relationship between intracranial pressure and obesity: an ultrasonographic evaluation of the optic nerve. Surg Endosc 2016; 30(06):2321-2325

5 Morrison JF, Sung KE, Bergman AM, Rosenblatt MS, Arle JE. A novel solution to reduce the complications of distal shunt catheter displacement associated with obesity. J Neurosurg 2010;113 (06):1314-1316

6 Sugerman H, Windsor A, Bessos M, Wolfe L. Intra-abdominal pressure, sagittal abdominal diameter and obesity comorbidity. J Intern Med 1997;241(01):71-79

7 Frezza EE, Shebani KO, Robertson J, Wachtel MS. Morbid obesity causes chronic increase of intraabdominal pressure. Dig Dis Sci 2007;52(04):1038-1041

8 Nakahara K, Shimizu S, Oka H, Utsuki S, Iida H, Fujii K. Migration of the distal end of a ventriculoperitoneal shunt into the abdominal wall in an obese patient: case report. Neurol Med Chir (Tokyo) 2009;49(10):490-492

9 Balakrishnan V, Jeanmonod R. Two episodes of ventriculoperitoneal shunt migration in a patient with idiopathic intracranial hypertension. Case Rep Emerg Med 2014;2014:280793 